http://dx.doi.org/10.4314/gjl.v7i2.9

\title{
LANGUAGE AND LIBERTY IN GHANAIAN POLITICAL COMMUNICATION: A CRITICAL DISCOURSE PERSPECTIVE
}

\author{
Samuel Gyasi Obeng
}

\begin{abstract}
The object of this study was to illustrate the entwining between language and liberty in Ghanaian political discourse. Using three letters written by Dr. J. B. Danquah (two addressed to President Nkrumah and one to the Speaker of Ghana's Parliament) and working within the framework of language and liberty (Obeng, in press), I demonstrate that even though by being candid, Ghanaian political actors in opposition risked personal danger, such actors had communicative ways for pursuing and defending their negative liberty and positive liberty and for challenging powerful political actors' oppressive and illegitimate actions. The discursive features employed to pursue liberty include: deferential mode of address, candour, inferencing, glittering generalities, emotional valence, politeness and intertextuality. The syntactic features used included conditional sentences, pronouns, physical verbs, lexical collocation and uppercase letters. The study concludes by submitting that liberty relies on language to become actuality and that political actors' views on liberty and the historical, legal, political and cultural contexts of the discourse ecology in which they operate all impact their discourse performance in their fight for liberty.
\end{abstract}

Keywords: language, liberty, law, Ghana, Danquah, Nkrumah

\section{Introduction}

Speech can be costly in Ghana despite the many traditional communicative maxims and axioms and constitutional provisions relating to free speech. Thus, despite free speech being clearly inserted in the various Ghanaian constitutions and in some Ghanaian ethnic groups' (such as the Akan) 'unwritten constitution' via the Akan communicative maxim Ananse Kokroko anton kasa, odemaa kwa (Big Spider' (God) did not sell speech, he gave 
it freely), both the spoken and written word can be costly if used without attention to the appropriate socio-cultural, political and juridical contexts of communication. In some of my earlier works on political discourse (Obeng, in press; 1997a; 1997b; 1997c), I note that there are safe mediums to express tabooed topics and that by using appropriate protective disguise, interactants may be able to make public, concealed aversion for political opponents' actions as well as such actors' views. In Obeng (1997a), I called for studies on political discourse to give appropriate weight to the diverging social principles of relevant cultures and of the varying degree of personal danger inherent in political ecology in which political actors function.

In this paper, I establish that language and liberty influence each other. Specifically, I prove that Dr. J. B. Danquah, via his letters to the Speaker of Ghana's Parliament and to President Kwame Nkrumah (Ghana's first President), established the difference between his thoughts and beliefs about liberty, and those of President Nkrumah. Using specific discursive and linguistic markers, Danquah criticized Nkrumah for trampling on his (Danquah's) and on other political actors' personal liberty. Danquah questioned his unlawful imprisonment and called for a restoration of his civil and personal liberty and, consequently, asked Nkrumah and his Convention People's Party (CPP) government to allow him to freely participate in Ghana's political and social processes. Furthermore, I establish that Danquah's choice of words provides us with access to his worldview of reality. As I note in Obeng (in press), for Danquah, his perpetual confinement and prohibition from partaking in Ghana's political activity was bad for both him and for Ghana's political process. To put this in perspective, I elucidate Danquah's role in Africa and Ghana's liberation struggle.

\subsection{Ghanaian Independence}

The European occupation of Ghana resulted in the appropriation of Ghana's human and natural resources, a denial of Ghanaians of their basic civil rights, and the fracturing of Ghanaian society. Borders created for Britain and other European colonialists' opportuneness cut through ethnic-based 'nation-states,' and empires in Ghana with impunity. For example, the Akan group were separated with a part of the Akan nation-state going to British Gold Coast (now Ghana) and the other half to French Cote d'Ivoire. For the Ewe, their nation-state was divided between the Germans and the French; the German 
part was given to Britain after Germany lost the war; the other half, Togo, 'belonged' to France.

During the colonial occupation era, the ethnic groups in the Gold Coast had little or no say in the administration of their own nation-states despite Britain's so-called indirect rule (see Obeng 2018). The indigenous populace was consigned to the margins of society and dispossessed of its basic civil rights and their mineral deposits, virgin forests, and human capital were exploited for the benefit of the British crown and its peoples. Indeed, colonization deleteriously affected the colonized peoples by creating patterns of inferiority and the absence of self-respect (Obeng, in press).

An important area of language where British colonization was openly displayed was in the field of onomasiology, especially, anthroponymy (Obeng 2001) and toponymy. Ghanaians were either forced to take or willingly took European and Judeo-Christian names. Others Europeanized their Ghanaian names. Some even saw Ghanaian cultures as heathen and their Ghanaian names as capable of invoking a curse on them and hence abandoned such names. The land mass now named Ghana was named Gold Coast in reference to the large deposits of gold found in the country. Parks (such as Victoria Park), roadways and streets as well as other important monuments and installations were either named after the British monarch or after so-called important British colonial government officials or military generals. Ghanaians, some of who had never set foot in Britain, studied for British university degrees and those whose service were judged by the British monarch as promoting Britain's interest were awarded the title, Sir; titles they wore with pride! Indeed, the action by the British of firing their cannons at 12 noon, were transliterated into Akan (Ghanaian language) concept and naming of time with 12 noon being referred to as prem-to-berc (cannon-firing-time).

During Ghana's liberation struggle, a political discursive distinguishing feature of the struggle was the appropriation and use of political terminologies like traitors, neocolonialists, exploitation, comrades, communalism, independence now, people's, masses, among others, by political actors of the Socialist inclination. For those political actors of the capitalist ideological orientation, words and expressions such as rule of law, law and order, friends, partners, reactionaries, independence at the appropriate time and with dignity, among others, became the mantra of that era.

Another important aspect of the interconnectedness between language and politics that was in-vogue during and immediately after the liberation was in the naming of important clubs and institutions. Note that during the colonial era, anything associated with blackness or black traits was looked down upon; even indigenous religions were subverted 
and replaced with European religions. To snob Britain and racist Europe for their hatred of Black people and anything black, the government of independent Ghana decided to name national sporting institutions with the word Black. The men's national soccer team was named the Black Stars, the women's, Black Maidens. Others were: Black Sticks (the national hockey team), Black Bombers (the national Boxing team), Black Meteors (Ghana's under 21 national soccer team), Black Starlets (Ghana's under 17 soccer team), among many others.

Given that Ghana's liberation struggle took place during and in the context of the Cold War, the liberation struggle was caught up and eventually couched in the politics of the time. The political context of the time thus affected the nature of the liberation struggle to the extent that the different political parties in Ghana found themselves becoming either pro-Socialist or pro-Capitalist. Political actors such as Nkrumah and his lieutenants, Kojo Botsio and Komla Gbedemah, were seen as socialist (communist) in leaning; whereas Danquah, Ofori-Attah, Obetsebi-Lamptey and others were viewed as sympathizers of the capitalist ideology.

The ideological divide in the direction of Ghana's independence movement between Nkrumah and Danquah led Nkrumah to split from the United Gold Coast Convention (UGCC), the main liberation force, to form the Convention Peoples Party (CPP) - the party that won Ghana's first parliamentary elections in 1951. The Gold Coast became the first British colony in Africa to achieve self-governance when it gained independence on March 6, 1957. Nkrumah become Ghana's first Prime Minister and when Ghana became a Republic on July $1^{\text {st }}, 1960$, Nkrumah became its first President. It is important to note that even though Ghana was considered the first Black African country south of the Sahara to gain independence, Liberia, which was a 'free' or 'independent' country made up of freed slaves from the United States of America (USA) and indigenous African ethnic groups, was already 'free' but its status as an independent nation-state was 'challenged' because of its linkage with, and perpetual dependence at that time on the USA, and more especially, because of USA's over-bearing influence on Liberia's political leadership and economy - the Liberian dollar was equal to and tied to the US dollar and so Liberia was seen by most Africans as Imperialist USA's territory.

The UGCC which had disbanded in 1951, later became the United Party (UP) and was the main opposition party from 1957 to 1960 at which time Nkrumah's CPP government passed the Avoidance of Discrimination Act, 1957 (C.A. 38); a bill which declared Ghana a one-party-state and banned the UP and other opposition parties such as 
the Anlo Youth Organization, the Ga Shifimopke, the Muslim Association Party, the National Liberation Movement, the Northern People's Party, and the Togoland Congress which Nkrumah considered confined to or identifiable with ethnic or religious groups. The ban took effect from December 31, 1957, which meant that the UP, the main opposition party, was an illegitimate party.

The ban on free multiparty democracy did not sit well with the opposition parties and the enmity between Nkrumah's CPP and Danquah's UP became so bad that Danquah and other political actors who Nkrumah viewed as a threat to his presidency were thrown into solitary confinement for years. This post-independence crisis led to several conflicts, military coups d'état, and economic depression in Ghana and it was in the context of the above political climate that Danquah, who was in jail on charges of treason for planning to forcibly overthrow Nkrumah and his CPP government, wrote the three letters that formed the basis of this study.

\subsection{Brief Biography of Dr. J. B. Danquah}

Danquah was born on December 18, 1895, into the most influential Ghanaian political family. Three relatives from the family, namely: J. B. Danquah, Edward AkuffoAddo and William Ofori-Attah, were among the founding fathers (referred to as the Big Six) of modern Ghana. President Nana Addo-Danquah Akuffo-Addo, Ghana's current president, is the son of former President Edward Akuffo-Addo and grandnephew of Danquah.

Danquah was a philosopher, lawyer, pan-Africanist, and a statesman in the West African sub-region. In 1925 he studied philosophy at the University of London earning his B.A. degree and in 1927, he completed his PhD in Philosophy with a dissertation titled "The Moral End as Moral Excellence." Danquah entered Britain's Inner Temple and was called to the United Kingdom Bar in 1926. His doctoral dissertation had considerable impact on his personal and professional lives and might eventually have led to his demise. As a philosopher studying morality and its impact on personal life and statecraft, he believed in the moral excellence and moral credence in governance. To that end, he passionately wrote about why personal fame and money-making should be taken away from politics, given that when personal and financial gain become part of politics then charlatans, not hard-working, qualified and sincere persons, flock into politics. Danquah also religiously spoke about liberty and defended it whenever and wherever. 
As part of his scholarly and professional journey on moral excellence, Danquah helped to initiate and actively participated in Africa's emancipation during his student-days in Britain. He established The West Africa Times which was earlier called The Times of West Africa, in 1931. He also edited the West African Student Union Magazine from 1926 to 1928. Both newspapers became the voice and mouth-piece of Africa's liberation struggle. Danquah became a member of Ghana's Legislative Council in 1946 and actively pursued Ghana's path to independence. In 1947, he worked with some businessmen led by George Alfred Grant and some Gold Coast chiefs, academics and lawyers to form the proindependence United Gold Coast Convention (UGCC). He was named leader of the UGCC with other prominent leaders being Ebenezer Ako-Adjei, R.A. Awoonor-Williams, Edward Akuffo-Addo, William Ofori-Attah, Alfred Grant (Paa Grant), Oheneba Ekow Richardson, Kofi Amponsah Dadzie, K Kesse Adu and Emmanuel Obetsebi-Lamptey.

On December 10, 1947, Kwame Nkrumah returned to the Gold Coast (Ghana) at the invitation of Danquah to become the UGCC's General Secretary. In 1948, following a boycott of European imports and subsequent rioting in Accra, Danquah, Nkrumah, AkufoAddo, Obetsebi-Lamptey, Ako-Adjei and Ofori Atta (referred to as the "the big six") as well as Oheneba Ekow Richardson, Kofi Amponsah Dadzie, and K. Kesse Adu were jailed for a month by the British colonial authorities for 'inciting' the riots.

As noted in the previous section, after independence, Danquah was thrown in jail on October $3^{\text {rd }}$, 1961, on charges of subversion under the CPP's Avoidance of Discrimination Act, 1957 (C.A. 38) also referred to as the Preventive Detention Act. After his release from jail on June 22, 1962, Danquah was rearrested on January 8, 1964 and sent back to jail for an alleged implication in a plot against President Nkrumah

Given the enormous role Danquah played in Ghana's independence to the extent of being named as the doyen of Ghanaian politics by the Watson Commission of Inquiry report of 1948, he did not take his incarceration by Nkrumah lightly. Most importantly, Danquah's philosophical perception of liberty (especially, his understanding of freedom from intrusion and freedom to participate in Ghana's political process made him view Nkrumah's actions as unlawful and unconstitutional. Indeed, being the chief architect of Ghana's first constitution, and being subjected to detention without trial (something which he as a lawyer saw as intrusion on his constitutional right), emboldened him to communicate his views and displeasure about his incarceration and denial of freedoms to the Speaker of Ghana's Parliament and to President Nkrumah no matter the consequences and injury to his person and to his political career. Danquah's philosophical perception of 
liberty fuelled his desire to fight for it irrespective of what the most powerful political actor, Nkrumah, felt. He (Danquah) died of heart attack in detention at Ghana's Nsawam Medium Security Prison on February 4, 1965.

\section{Method}

Three letters written by Danquah formed the basis of this study. The first letter was written on January 30, 1962, to the Speaker of the National Assembly and was titled "Nothing but the Truth." The second letter was written to President Nkrumah on January 8, 1965, titled "Demand for Immediate Release and Opportunity for Offer of Amends," and the third was written on January 23, 1965 and was intended to be an apology about his second letter having made Nkrumah angry.

The letters were chosen first and foremost because they are political in nature, were written within a political ecology, and were written by Danquah, one of the most prominent political actors (founding fathers) during Ghana's struggle for independence. Danquah led other political actors in the framing of Ghana's first constitution; he also wrote more about liberty from both academic and professional perspectives than any other Ghanaian political actor at the time. Indeed, his book titled The Liberty of the Subject, dealt with what became known as the Cocoa Hold-up and the subsequent boycott of European goods (Nowell Commission on the Hold-up of Cocoa, 1937-38). Thus, his academic, legal, and political background as well as his role in Ghana's independence movement and his expertise as well as his lived-experience involving denial of him of liberty, provide validity and credence to him being a politician and the content of his letters being politically-oriented and politically situated.

Furthermore, the data contained the speech acts of political: (a) criticism about the Executive's (Nkrumah's) and the Legislature's (CPP's) inattention to the constitution of order and fairness; (b) complaint about the Executive's inattention to liberty, the basic tenets of democracy; (c) apology (which involved apologizing for an earlier mail that supposedly made Nkrumah angry), and (d) request via which he asked Nkrumah to free him from a politically-motivated jail and an incarceration that he believed to be illegal. Through the data, we can demonstrate how Danquah appropriated various discursive strategies to let us into his worldview about liberty, how and why he sought liberty for one and all, and his desire to protect liberty once won. To understand how Danquah achieved the above communicative and political tasks, I briefly discuss the theoretical framework within which the study was carried out. 


\section{Theoretical Framework}

This study is done within the theory of language and liberty (Obeng, in press). In working within this theory it is important, firstly, to establish the fact that liberty, as a philosophical and legal concept, depends on language to become an actuality given that language is used to express liberty and its associated concepts. Also, liberty invokes and finds expression and realization in law and in politics. Following Sir Isaiah Berlin's (1960) work titled, Four Essays on Liberty, in which he elucidates the philosophical underpinnings of liberty, I note that liberty should be viewed from two perspectives-liberty from, also known as negative liberty, and liberty to also known as positive liberty. Liberty from (negative liberty) involves the protection of individuals and minorities from the intrusions of the government and others into their fundamental freedoms. Liberty to (positive liberty), on the other hand, guarantees the right of individuals to participate in the process of government and to share in the political power of their communities or states; the right to self-determination of the various levels of political community (Berlin 1960).

As Berlin (1960) and Date-Bah (2008) note that governments must put in place the material conditions for maintaining liberty to ensure that individuals are guaranteed liberty. Specifically, there is the need for a legal structure to be preserved in a nation's instrument of government and in judicial precedent to ensure that individuals' liberties are guaranteed. This is because as Date-Bah (2008) notes, failure to enshrine a Bill of Rights in a nation's constitution has the potential of creating a situation in which political actors in power become tyrannical and infringe on individuals' freedoms (their negative liberty) and their positive liberty with impunity because they are not subjected to law. In the case of Ghana, the absence of a tradition of subjecting government to law at the time, enabled the CPP government to pass the Avoidance of Discrimination Act, 1957 (C.A. 38) also referred to as the Preventive Detention Act of 1957/58 immediately after independence and this, according to Date-Bah (2008), subsequently enabled Nkrumah to engage in human right abuses using what Date-Bah refers to as parliamentary supremacy that was provided for in Ghana's Independence Constitution of 1957. Furthermore, as Date-Bah (2008) surmised, even though the Ghanaian courts may have thought that they were implementing a law left for Ghana by the British common or constitutional law, the main legal conundrum was that whereas the British Parliament put up with divergent views, not only did the Ghanaian Parliament under Nkrumah inhibit divergent views, such views were considered treasonous 
and political actors who held such views were consequently incarcerated with and without judicial due process.

Framing the analysis of Danquah's letters within the theory of language and liberty will help to prove the extent to which he saw both his negative and positive liberty trampled upon by the Ghanaian Executive and Legislature. As a philosophical concept, Danquah, a leading philosopher of his time, must have been aware of liberty being entrenched in Ghanaian thought via the various ethnic groups' communicational mores and maxims. As an Akan-born, he must have been aware of the two Akan axioms: Ananse Kokroko anton kasa, odemaa kwa (Big Spider' (God) did not sell speech, he gave it freely)); and Woankasa wo ti ho a, yeyi wo ayibone (If you do not complain about your haircut, you get an ugly haircut). The first axiom points to an individual's unalienable right to free speech, and the second, to one's right to complain about and seek redress from mistreatment and to prevent others from infringing on their right to seek freedom from abuse and exploitation. Danquah's letters explicitly demonstrate that he rejected Nkrumah's use of his position of power to intrude his (Danquah's) negative liberty and to infringe upon his positive liberty; consequently, he called on Nkrumah and the Speaker of Ghana's Parliament to desist from their oppressive behaviours of flouting both liberties openly and with impunity. As a legal construct, Danquah, a legal luminary and a party to the framers of Ghana's first constitution, was aware of the separation of powers, which branch of government made the laws, who interpreted them, the due process regarding the laws application in the right juridical ecology, and what can happen if people elected to oversee government business and the judicial process neglect to follow due process.

Working within the theory of language and liberty requires us to examine the most important discursive and linguistic tools within which the fight for liberty finds expression. Specifically, we examine the lexical items and phrases as well as sentence types in which request for liberty are formulated as well as the discourse-pragmatic strategies such as inferencing, speech act types, deferential modes of address, politeness markers, as well as openings and closings used in seeking liberty (Obeng in press).

\section{Aims}

In this paper, we demonstrate that political actors without political power have discursive strategies for seeking and safeguarding their negative and positive liberty and that such strategies may be used to challenge the validity of claims made by those in power 
despite the discourse being asymmetrical. Also demonstrated is the fact that language and liberty are intertwined.

\section{Findings and Discussion}

The first observation we put forward relates to the interconnectedness between language and liberty and is stated as follows: powerless political actors may speak vehemently for and about liberty irrespective of whether or not their pronouncements will result in being thrown into or kept in jail indefinitely, and that through their language we are brought into such political actors' worldview about how language and liberty inform each other. Thus, we observe that in asymmetrical power-oriented political discourse, despite being powerless, political actors in opposition have discursive strategies for raising and challenging the validity of claims and political actions of political actors in power. This observation contradicts that of Harris (1995:49) who argues that 'in non-congruent interactions there is an asymmetrical distribution of speech acts as a mode of strategic communication preventing validity claims being raised or challenged except by powerful institutional representatives.' Thus, via his letters, Danquah proves that without power, he still had discursive resources at his disposal to speak back to Nkrumah about liberty. On the other hand, given that Danquah died as a political prisoner, one could also argue that political actors who are not in a position of power and who resort to candour in their fight for liberty risk death. Six extracts are cited in support of the above observations. Note that the cited extracts are just six of the many cases that help illustrate the observations.

\section{EXTRACT 1}

On January 30, 1962, Danquah wrote from his jail cell in Ghana, to the Speaker of Ghana's Parliament about his unlawful arrest and detention. Source: "Nothing but the Truth' (Petition from detention at Ussher Fort Prison)" from Historic Speeches and Writings on Ghana by J. B. Danquah (Akyeampong 1966: 154).

Danquah: Sir, A Petition to the Parliament of Ghana through the Speaker of The National Assembly. I, the undersigned free citizen of Ghana, arrested and detained on 3rd October 1961..... "Open my eyes that I may behold the wonders of thy law." I am compelled to 
seek the intervention of the Legislative Authority of Ghana for the Executive Authority to provide redress for my grievances as a subject of the law, and a citizen of the State. The irregular, unjust and lawless manner in which the Government of Ghana has dealt with me, as with the other detainees arrested on or about the 3rd October 1961, (i.e., 172 of 1961) is the reason for this.

In the above extract (Extract 1), Danquah complains about: Nkrumah's denial of him of his negative liberty via intrusion into his fundamental freedoms and his positive liberty via a denial of him to participate in the process of government and in the sharing of the political power of his community. Danquah saw Nkrumah's denial of him of access to the courts of Ghana as being in direct contravention of a provision in Ghana's Republican Constitution of 1960, and as a violation of his Common Law right to have his day in court. Nkrumah had suppressed, from the public and press, the statutory "Representations" made by Danquah at the Nsawam Prison on October 13, 1961, in answer to the Statutory "Grounds for Detention" served on him (Danquah) within five days of his arrest. Meanwhile, Nkrumah's CPP government published a White Paper containing new and unchartered "Grounds for Detention" against Danquah, but these were not served on Danquah within the statutory five days, or at all. Furthermore, Danquah argued that the White Paper was not issued in accordance with the provisions of the Preventive Detention Act, 1958 (Akyeampong 1966: 154-172). It is important to note that Danquah was arrested on October 3, 1961, but the White Paper on his arrest was published on December 11, 1961 (69 days after his arrest).

From the extract, we observe that Danquah viewed Nkrumah's action as a gross irregularity from the point of view of Ghana's jurisprudence. He (Danquah) yokes together two contrasting issues: that of being detained and yet being 'free.' An observation of the text reveals that there is an incongruity between the actual result of the sequence of events and the normal expected result - an issue that creates a situational and dramatic irony (Obeng 2016). By the expression, "I, the undersigned free citizen of Ghana, arrested and detained," Danquah is suggesting that freedom can be viewed from different levels, and that being imprisoned does not take away one's freedom to fight for liberty or protest his imprisonment. One could view Danquah as a character in a "legal drama," seeing himself as a 'free' citizen whose liberty had been intruded upon and who, by the Executive's intrusive act, had suffered loss of both his negative liberty (because the Executive by its unlawful action had encroached on his personal freedom) and his positive liberty given that 
his incarceration prevented him from participating in his family life, his academic life (as an author whose dream was to continue writing about his people), his social life and his politico-cultural life (as a chief and a leading political actor).

Viewed from another angle, it could be argued that there was a pretence of ignorance on the part of Danquah and a kind of willingness on his part to learn from the Executive (Nkrumah) to make Nkrumah's false conceptions about liberty conspicuous by adroit questioning. Thus, in this political and juridical 'drama', Danquah implicitly: (a) identified Nkrumah's ignorance and inattention to the law; (b) pointed to the legislature's turning of a blind eye to Nkrumah's wilful disregard of and for the law; and consequently, (c) sought redress, a restoration of his negative and positive liberty, through the legislative body.

Viewed from an angle that makes the Executive (Nkrumah) the main character in the politico-juridical saga, one observes a dramatic irony as well as a tragic irony. The audience (including the public and the victim - Danquah) understood the denial of liberty done via the injustice and lawlessness perpetrated by the Executive in collaboration with the Legislature, but the main characters, the Executive and Legislature, did not appear to understand it. As noted in Obeng (2016), by appropriating the biblical text, Danquah was engaged in indirectness, an insinuation, by pleading with "God" to open the Ghanaian Parliamentarians' and Nkrumah's eyes so that they would understand the tenets of liberty (the 'wonders' of Ghana's laws and constitution) and not deny others of them (liberty). As noted in this paper, Danquah, a constitutional lawyer, led other political actors and legal personnel in the drafting of Ghana's first constitution so he understood its tenets and juridical implications. Nkrumah, having been invited by Danquah to join Ghana's independence struggle movement, and being a member of the nation's founding fathers, must have been aware of the scope and extent as well as the 'dos' and 'don'ts' of Ghana's Republican Constitution, and the constitution of order, so turning a blind eye to the very laws he (Nkrumah) swore to uphold made his rule illegitimate given the wilful and malicious nature with which he treated his opponents.

Danquah engaged in delegitimization (in the sense proposed by Chilton (2004)) of the action taken by Nkrumah by creating an "other" worldview that portrayed Nkrumah's action as being different from the 'right' legal norm. By so doing, Danquah distanced himself from that "other" (Nkrumah) by portraying the differences between his stance and worldview on liberty and upholding it as opposed to that of Nkrumah which involved flouting other people's liberty and thus involving lawlessness. Specifically, Danquah's 
delegitimization of Nkrumah's actions encompasses the speech acts of criticizing, blaming and accusing. He positioned himself as someone knowledgeable about Ghanaian law and constitution and as a victim of lawlessness. He then positions Nkrumah as being ignorant about the law and, hence, a perpetrator of lawlessness, and the Legislature as having the power and expertise to make laws and follow the constitution, but passing a 'questionable' law and then turning a blind eye to his (Danquah's) predicament.

Viewed from the perspective of Habermas' $(1984,1992)$ validity claims, we can argue that Danquah used this letter and the cited biblical text to lay claim to understandability, truth, and rightness; and, to accuse Nkrumah of lacking an understanding of the law, of shunning from the truth, and of taking a wrong stance towards his (Danquah's) 'wrongful imprisonment.' The biblical passage used by Danquah in Excerpt 1 is from Psalm 119: 18. Danquah, in using the biblical text, criticizes the Executive, the Judiciary and the Legislature (Ghana's National Assembly) for not living by the tenets of the law, but rather disregarding them. He appeared to be asking, 'Where have the Legislature and Judiciary been all this time when the Executive was breaking the law by intruding on individuals' liberty?'

From the point of view of intertextuality, the biblical passage helps Danquah to draw attention to the need for people in power to recognize people's negative and positive liberty and to uphold such liberty by defending the supreme laws of the land over which they rule. Through the voice of David, the Psalmist, Danquah was submitting that knowledge of the laws regarding liberty and the correct interpretation and application of such laws bring freedom, justice, and lawful behaviour; whereas, ignorance about, or inattention to the laws regarding liberty, as well as the misinterpretation and misapplication of such laws bring imprisonment, human suffering, injustice, and lawlessness, all of which intrude on individuals' negative and positive liberty.

Using the biblical texts served Danquah's philosophical, juridical, political, and communicative strategic ends. By citing from the Bible, Danquah revealed the delicate power imbalance and social injustice in Ghanaian society at the time of his writing. The intertextual relations between the biblical text and his message served to heighten the political tension in Ghana in the early to mid-1960s.

In the next extract, Danquah explains the grievance regarding denial of him of access to the Courts of Ghana; a denial which he viewed as a contravention to a solemn provision in the Ghanaian Republican Constitution of 1960. 
EXTRACT 2 (Context: Same as Extract 1)

When therefore the Minister of Interior, at the instance or otherwise of the Government of Ghana, oppressively prohibits or refuses to permit any lawyer to visit any of us in prison he thereby denies or takes away from us our constitutional and common law right of access to the Court. In my case I have written to Mr. Koi Larbi, Barrister-at-Law of Accra to request him and Messrs. R.S. Blay and W. E. A. Ofori-Atta and de Graft Johnson, all Barristers, to visit me for consultation, but in no case has permission been given for any of them to gain access to me in prison.

In the above extract, Danquah viewed the denial of him of access to the Courts as an intrusion on his liberty given the fact that the denial took away his Common Law right to have his day in Court. As Danquah noted in the letter of January 30, 1962, when one's liberty is interfered with by anyone, it is the Judicial Authority (the Court) that becomes the individual's constitutionally appointed sovereign to judge between the individual and the respondent; in the current case, between him, Nkrumah and the Legislature. Taking away his (Danquah's) Common Law right therefore infringed on both his negative liberty (protection from the intrusions of the government and others into his fundamental freedoms) and positive liberty (his right to participate in the process of government and to share in the political power of his community or the state (Ghana).

Extract 2 illustrates Danquah's use of a conditional sentence. The conditional clause, when therefore the Minister of Interior, at the instance or otherwise of the Government of Ghana, oppressively prohibits or refuses to permit any lawyer to visit any of us in prison, states the condition, and the main clause, he thereby denies or takes away from us our constitutional and common law right of access to the Court, expresses the result of the condition. The subordinating conjunctions of the sentence are when, therefore and thereby. Via the conditional sentence, Danquah challenges the illegitimate action of the Executive (the President and his Ministers) by arguing that by preventing the detainees' lawyers from visiting them in prison, the Minister of Interior (at the instance of the Government of Ghana) was intruding upon his and the other prisoners' freedom (negative liberty) and their positive liberty. Danquah's use of the adverbial expression oppressively prohibits or refuses ... depicts his abhorrence of oppression and the intrusion on his liberty and how he viewed the Executive's lack of understanding of liberty. If the Executive understood the philosophical and legal tenets of liberty, it would have refrained from taking 
it away from its citizens. Furthermore, the expression, take away from, suggests that individuals, in theory, possess unalienable constitutional and common law right of access to the courts and that taking such rights away from them is an infringement on their liberty and is hence, illegal and unconstitutional.

From the above discussion, we could argue that Danquah's fight for liberty became reality through his use of language (specific lexical items and syntactic constructions). His understanding of the law on liberty regarding the rights of incarcerated persons and of how the law works helped him to frame his objections to the Executive and Legislature's illegitimate actions and that emboldened him to fight for his liberty regardless of the consequences.

In Extract 3, Danquah uses his letter sent to Nkrumah to criticize him (Nkrumah) for the mass incarceration of his opponents on 'trumped up' charges of sedition and treason.

\section{EXTRACT 3}

My wife's distress over her own feeling that I appear to have hurt Your Excellency is quite understandable for she, like many of our countrymen, is frightened of the situation today, where our country, which formerly did not know of seditions, not to mention treasons, is now fully of interminable treason trials and numerous number of secret detentions over which no one seems to have any remedy but to capitulate and to pray earnestly that God may one day be pleased to save Ghana from this curse.

In the above extract, Danquah employs emotional valence, via his wife's distress, to challenge power, namely, Nkrumah's arbitrary arrest and detention of his opponents for sedition and treason, something unknown in Independent Ghana prior to Nkrumah's actions. An important discursive strategy employed by Danquah is the use of a deferential mode of address; he refers to Nkrumah deferentially as Your Excellency. The extent of the arbitrary arrests, detentions and trials is captured in the collocating expressions, interminable treason trials and numerous number of secret detentions. Danquah shows his abhorrence for what he saw as Nkrumah's unlawful actions by describing it with the noun, curse. Thus, by resorting to the use of emotional valence, a deferential mode of address, collocation, and choice of a noun that denotes the invocation of the supernatural to inflict harm, Danquah was able to challenge what he perceived as Nkrumah's encroachment on his political opponents' liberty and his abuse of power in taking unlawful actions. 
In the next extract, not only does Danquah complain about what he saw as his unlawful arrest and detention, he candidly noted the wrongful action of Nkrumah and his CPP government by 'educating' Nkrumah on how he and his government should have acted towards him - thank him for his contribution to nation building and the national political discourse.

\section{EXTRACT 4}

My next petition, in order of time, but first in order of importance, was the one dated the 12th of June, in which I set out the entire course of my life and 'activities', from June 1962, when I came out of the first detention, to January 4th, 1964, when I was again arrested. And I believe I made a case in that letter which, looked at fairly and squarely, what the Government of Ghana, with Your Excellency as the head, should have done for me was to send a distinguished national delegation to thank me for my contribution to the nation's wealth of thought, culture and progress, instead of sending against me hostile troops of the Ghana Army to invade me and destroy my home life as if I was the greatest felon and the vilest enemy of our beloved land.

In the above extract, Danquah candidly informs Nkrumah that he (Nkrumah) did not look at his (Danquah's) earlier petition fairly and squarely hence his undertaking of an action, that of sending the Ghana Army to invade [him] and destroy [his] home life. The extent of the intrusion on his liberty is couched in the bluntness of the petition which is expressed via the use of:

(a) the adverbial expression, fairly and squarely which by inferencing suggests negligence on Nkrumah's part in consideration of the case on its merit as well as Nkrumah's inattention to the facts of the case even when such facts were overt and simple; and

(b) the prepositional expression, with Your Excellency as head, suggesting that Danquah put the blame of his arbitrary arrest and continued incarceration without due process and due diligence, and turning a blind eye and consequent denial of his negative liberty (his imprisonment) and positive liberty (the denial of him to participate in his home life and in nation building) on Nkrumah. 
The cohesive import of such collocations as fairly and squarely, hostile troops, distinguished national delegation, greatest felon and vilest enemy vividly and lucidly describe what Danquah's perception of Nkrumah's actions were (that of illegality in the arbitrary arrest and detention of opponents) as well as what his (Danquah's) intentions were, and what he wanted Nkrumah to take from the letter - the need for Nkrumah to look at the facts of his case and stop denying him his liberty and civil rights. Thus, we see the petition of the oppressed and powerless Danquah, couched not in indirectness as we often see in the discourse of African political actors without power (Obeng 1997a), but in candour.

Furthermore, the pronoun pairs $I$ and me, and you and your found throughout the extract point to candour in the fight for liberty. With the pronouns, $I$ and $m e$, Danquah was able to focus attention on himself. Through these pronouns, he appeared to be saying: ' $I$ am the one who has been wronged and unjustly imprisoned several times.' However, the pronouns, you and your, refer to Nkrumah and his CPP government. Danquah appeared to be saying, 'You and your government have used the military to wrong me because of your power which you are abusing.' Use of the above pronouns helped to create the political communication strategy of 'us vs. them,' through which positive self representation and negative other representation are rendered (van Dijk 2004). Via the pronouns and the antithetic expressions, should have done for me and instead of sending against me, Danquah draws attention to the good expected of the Executive and Legislature and the bad action that they did to him. Thus, Danquah amplifies how the Executive, acting in concert with the Legislature, ignored their duty of protecting their citizens and instead, intruded on the citizens' liberty.

Finally, Danquah used the physical verbs, invade and destroy, which are verbs denoting physical sensation, to demonstrate the violent nature of the intrusion on his liberty and the resulting injurious nature of the invasion; a destruction of his person and of his home life.

In sum, we observe that via his choice of words Danquah candidly and explicitly shows how, despite being powerless, he was able to show the impact of Nkrumah's intrusion on his liberty and how Nkrumah's actions affected his person, his profession and his home, and the potential of Nkrumah's actions to lead to his ultimate demise - something which happened.

In the next extract, Danquah makes further effort to draw President Nkrumah's attention to his (Nkrumah's) infringement on his (Danquah's) positive and negative liberty. 


\section{EXTRACT 5}

May I, in this connection, recall that my first petition of the 21st May, 1964 for my release on cultural and humanitarian grounds, laid much stress on the fact of what we both held in the reverence and believed in common, Africa and the greatness of Ghana. I urged upon you in that letter that to enable me to continue my cultural contribution to these great ideals, it was useless keeping me in prison, kicking my heels away from the work I love, my profession, my duty to my family and children, and the books and the learned societies which help the advancement of these imperishable ideals. I much regret to say I was not honoured with any reply from you to this letter, despite its great human and scholarly appeal.

In Extract 5, Danquah, first, resorts to intertextuality by referring to a text (his letter of $21^{\text {st }}$ May, 1964) whose content was known to both him and Nkrumah. By making an intertextual appeal to his previous text, Danquah is calling Nkrumah's refusal to reply to his letter, an unprofessional act that infringed on his (Danquah's) right to receive a response to his letter sent to Nkrumah. The expression, I much regret to say I was not honoured with any reply from you to this letter, despite its great human and scholarly appeal, not only draws attention to the lack of response from Nkrumah, it also calls Nkrumah's attention to the 'great human' and 'scholarly' appeal of that letter. The words in the expression, great human and scholarly appeal, collocate. The expression also has embedded in it, the quality of glittering generality (words of virtue). Danquah appears to be arguing that if the letter of $21^{\text {st }}$ May 1964 had virtuous words in it, then the Executive ought to have taken note of it and at least responded.

What is most important about Extract 5, however, is Danquah's call on Nkrumah to stop intruding on his negative liberty. Danquah felt that besides taking away his freedom (his negative liberty), continually detaining him also prevented him from exercising his positive liberty which involved allowing him to make contribution to Ghanaian culture (something which he wrote about and also practised), his family and children's life, and to his legal practice (something which he indicated in his letters had suffered greatly due to his incarceration) and legal community (the Ghana Bar Association of which he was the president. Thus, via this extract, Danquah is showing the close connection between one's negative and positive liberty and how an action taken to encroach upon one leads to infringement on the other. 
An important comment worth noting relates to the expression, my duty to my family and children. For a person from a non-matrilineal society, one may question why Danquah mentions family and then children. In Akan society, even though a man's children are not members of his lineage (family), but are of the wife's lineage (family), a man is required to educate, feed, shelter and protect his children. A man who does not perform these duties is referred to as kwaseampani 'chief of fools' a label which if tagged to a man not only shames him but excludes him from public, social and political discourse since someone will most certainly raise this if the man attempted to speak at a public forum. Thus, participation in the affairs of one's matrilineal extended family, of one's spouse, and of one's children are required of anyone who wants to be recognized as a man and as a political actor.

In the final extract (Extract 6), Danquah challenges Nkrumah's intrusion on his negative and positive liberty on legal grounds and calls for a restoration of those liberties.

\section{EXTRACT 6}

My last communication is the one on 8th January, the one which appears to have greatly upset my wife ... On this occasion she travelled all the way to Nsawam, 20 miles or so, to see me because she had been upset by my annoying you. This last letter, was of course, not a 'representation' or a petition. It was a lawyer's letter of demand on the grounds that my detention was illegal and that I should be released immediately, and an offer of amends made by you, your Ministers and the Government of Ghana for the horrible damage you and they have caused me, including the breaking-up of my home, the damage to my legal profession and to all the great values I hold dear for Ghana and the world, as well as, of course, as to my family.

In the above extract, Danquah uses the expression, it was a lawyer's letter of demand on the grounds that my detention was illegal, to draw Nkrumah's attention to his disregard of and for liberty and the rule of law. As noted earlier, Danquah saw his detention as infringing on his negative liberty, a liberty he, Nkrumah and others fought to restore during the colonial era. He therefore demanded his release from incarceration by Nkrumah. The expression, a lawyer's letter of demand, involves candour and suggests that he was aware of and ready to fight for his liberty. In legal parlance, to demand that an action be taken is to suggest that a law had been broken or misinterpreted leading to a wrongful action such as wrongful incarceration of a person or injuring the person legally, and hence 
seeking redress by way of the law. To demonstrate the fact that he saw himself as having been wrongfully mistreated and imprisoned without due process, he calls, not only for his immediate release, but also for an apology and appropriate compensation. Danquah is not shy about the nature of crime committed against him; he refers to it as, horrible damage, and then enumerates the crimes "including the breaking-up of my home, the damage to my legal profession and to all the great values I hold dear for Ghana and the world, as well as, of course, as to my family." The discursive markers through which Danquah couches his expression is worth noting. The verbs, damage and breaking up are physical verbs and denote destruction and injury - acts which take away what one had, and which may or may not be replaceable. To break up and/or damage one's home is to take away one's positive liberty because losing such a right prevents one from participating in the affairs of one's livelihood, extended family, and one's marriage.

From the above extract and discussion, we observe how Danquah via his letters used language to express his views on liberty and how the quest for liberty 'emboldened' him to fight for it. We also note Danquah's use of various discursive strategies to fight for non-intrusion on his negative liberty and the protection of his positive liberty.

\section{Conclusion}

Considered from the point of view of philosophy, especially from Sir Isaiah Berlin's (1969) theory on negative and positive liberty, something that Danquah often spoke and wrote about, we hope to have demonstrated that Danquah, via his letters, asked for both Liberty from and Liberty to. Specifically, Danquah requested the right to be free from intrusions from the State and others (Liberty from) as well as the right to participate in the process of governance, to share in the political power of Ghana (Liberty to), and to participate in his private, family and professional lives. The evidence drawn from the data showed that language and liberty inform each other and that it was through language that Danquah's views on liberty became a reality.

Furthermore, an observation of Danquah's letters suggests that his texts were influenced by the historical, social, political and cultural contexts in which he wrote those letters, as well as his language and cultural ideologies, his interactional goals, and his intended outcomes. In managing such politically delicate speech acts as criticisms, complaints, disagreements, and requests, Danquah employed communicative strategies that generally differed from those of other political actors who were in jail with him. Thus, 
although Ghanaian language ideology assumes that political actors in opposition are not as communicatively powerful as those in power, this study has shown that Danquah sometimes ignored this communicative stance and communicated to Nkrumah like someone with whom he was on equal power terms. This, I argued, may have been because having been jailed together with Nkrumah and hence knowing Nkrumah's familiarity with the rule of law, constitution of order, and administration of justice, he expected Nkrumah to see the political world from his (Danquah's) camera angle.

Moreover, we are made aware, via Danquah's letters, the complexity encapsulated in the political and legal use of language. Power relations, we observed, are deeply rooted in legal, cultural and political mores and ideologies and effective use of language helps produce and reproduce power relations and provides tools for fighting for liberty. There is no doubt that this study clearly invoked power relations and concepts of power as expressed through language use in political texts, where status, rules, and strategies occupied centre stage for the political actors. What is interesting is the fact that questions concerning relations of language, law, power and liberty arose regarding who the political actor was, what his political ideologies were, and the speech acts and speech events in which he was engaged. In effect, we could argue that language behaviour in a political ecology, as measured in terms of candour, is intricately coordinated with political actors' stance on liberty, their worldview of liberty, how strongly they view liberty and its relation to power, and how far they are willing to risk their own lives and freedom by candidly seeking liberty instead of giving up on words. As Danquah's wife pointed out to him, his letters made Nkrumah angry, yet Danquah felt the need to write to protest his incarceration and to seek liberty.

Among the discursive strategies employed in the fight for liberty were deferential modes of address and reference, politeness, candour, inferencing, glittering generalities, emotional valence and intertextuality. The grammatical features used included conditional sentences, political pronouns, physical verbs denoting destruction and injury, pronouns (especially, inclusive and exclusive pronouns), collocation, as well as adverbs and adverbial constructions. Also, from the data it was observed that Danquah used an important graphological feature, that of upper-case letters, to show emphasis. Furthermore, as Obeng (1997a) argues, Danquah's use of upper case letters helped to demonstrate his frustration at Nkrumah's lack of understanding of the rule of law and how government works, especially, regarding to which office political prisoners must make legal and political representations. 
However, this study, like Obeng (1997a) has confirmed that knowledge of the interconnectedness between language and liberty goes beyond a mere list of correlations between discursive forms and liberty; it entails an understanding of how in seeking liberty political actors employ specific discursive forms to criticize, complain, request or apologize, and the norms of the political discourse ecology within which liberty is sought. It is important to also note that given that liberty is a philosophical and an ideological concept, in seeking it, Danquah ensured that his ideological preferences and expectations impacted the performance of his above-mentioned discursive tasks through which his fight for liberty was framed. Furthermore, being aware of the intertwining nature of language and liberty, and the power relationships between him and Nkrumah, Danquah framed his strategy of discursive performance to reflect these.

Throughout this study, we argued that Danquah's decision to resort to candor and political criticism of Nkrumah contrasted sharply with that of the other political prisoners namely William Ofori-Attah, Edward Akuffo-Addo, Mr. Ako-Adjei and others who decided not to communicate their displeasure about their wrongful incarceration to Nkrumah and who were consequently freed from jail. However, it is important to note that Danquah felt that fighting for liberty the way he did was in accordance with Ghana's constitution of order, its jurisprudence and political ecology. He regarded freedom from prison and a return to normal life as a return to the dynamic relationship between one and the practical affairs of one's country's political and juridical action and social affairs. Thus, he viewed a nation's achievement of survival and realization of the security and happiness of its citizens as a function of the exercise by its individual members to freely contribute their unique talents and qualities and to the making of liberty for all, a reality. Danquah therefore saw intrusion on one's negative liberty as a hindrance to the espousal of liberty.

The above discussion also shows the close connection between language and liberty. Nkrumah had political power and hence determined whether Danquah's letters were appropriate pathway for seeking liberty. Given that it was alleged (by Mrs. Danquah) that Danquah's letters made Nkrumah angry we could conclude that Nkrumah did not approve of them (the letters). As Danquah himself noted in one of his letters, he could have engaged in triadic communication by asking such a respected pseudo-epicentre as Nana Sir Tsibu Darku to negotiate on his behalf. We could argue that Nkrumah implicitly used Danquah's letters to reassert the differing power hierarchy between him and Danquah; an act that offered a glimpse about the strong interdependence between language, law, power and liberty. 
Also, from the letters we learn about the connection between liberty, power and politeness. Danquah's discourse opening (the salutation), his use of address and referential forms, and his discourse closings all point to his performance of politeness. The fact that Nkrumah refused to grant him his request of release from incarceration leading to his ultimate death suggests that power may override politeness and that the discursive type used (letter-writing) which Nkrumah viewed as improper and possibly 'dangerous,' overrode Danquah's use of politeness strategies. In Ghanaian society, oral communication is sometimes preferred to written communication when it comes to matters relating to law and governance since it is believed that written communication is evidentiary and difficult to dispute in a court of law. I would therefore like to submit that had Danquah gone the route of engaging a respectable Chief (as noted in the previous paragraph) to plead on his behalf in his fight for liberty, Nkrumah may have more likely heeded his request and freed him from detention.

Like Obeng (1997a), this study has implications for contemporary Ghanaian politics and jurisprudence. Specifically, Danquah's strategy of fighting for liberty via written medium has been appropriated by contemporary Ghanaian political actors. During the dictatorships of the Armed Forces Revolutionary Council and People's National Defence Council during which time Ghanaians' liberty was intruded upon with associated planned public and private executions, a culture of silence was created. It was the adherents of the Danquah ideological orientation (led by a History Professor, Adu Boahene) who, following Danquah's footsteps, broke the silence and openly fought for their liberty by challenging the authorities. It was the desire for liberty that eventually led to Ghana's current constitutional democracy. Like Danquah's use of the media, during the fight for Ghana's independence and thereafter, the Ghanaian media continue to seek liberty for Ghanaians by bringing to book, actors who infringe on the liberty of other political actors and the citizenry.

Finally, Danquah's use of the courts to seek redress on matters relating to liberty continues to play an important role in contemporary Ghanaian governance and jurisprudence. Ordinary Ghanaians have been emboldened to take governments or Presidents to court if they feel aggrieved. Also, the Ghana Academy of Arts and Sciences, a watch-dog of Ghana's governance and liberty, organizes annual lectures to showcase Danquah's contributions to Ghana's democracy. Danquah, thus proved through his letters that despite restrictions sometimes placed on free speech and infringement on negative and positive liberty, Ghanaians, in participating in the collective enterprise of nation-building, 
Gyasi Obeng: Language and Liberty in Ghanaian Political Communication: A Critical Discourse Perspective

must seek and protect such liberty at all cost and never be afraid to talk back to authority if they face any form of oppression and injustice. 


\section{References}

Akyeampong, H. K. 1966. Journey to Independence and After (J. B. Danquah's Letters) 1947-1965. Accra: Waterville Publishers.

Berlin, Isaiah. 1960. Four Essays on Liberty. Oxford: Oxford University Press.

Danquah, Joseph Boakye. 1970. Journey to Independence and After -1947-1965. Accra: Waterville Publishing House.

Date-Bah, Samuel Kofi. 2008. On Law and Liberty in Contemporary Ghana. Accra: Ghana Academy of Arts and Sciences.

Harris, Sandra. 1995. "Pragmatics and power." Journal of pragmatics 23(2): 117-135.

Labov, William and D. Fanshel. 1977. Therapeutic discourse: Psychotherapy as conversation. New York: Academic Press.

Martin, D. and P. Johnson. 1981. The struggle for Zimbabwe. Boston: Faber and Faber. Nowell Commission 1937-38. On the Hold-up of Cocoa. Accra: Gold Coast Records.

Obeng, Samuel. 1997. Selected Speeches of Kwame Nkrumah. Accra: Afram Publications.

Obeng, Samuel Gyasi. In press. "Grammatical Pragmatics: Language, Power and Liberty in African (Ghanaian) Political Discourse." Discourse and Society 29 (7).

Obeng, Samuel Gyasi. 2016. "Biblical Intertextuality in Ghanaian Political Text and Talk." Issues in Political Discourse Analysis. 5(1): 23-46.

Obeng, Samuel Gyasi. 2001. African anthroponymy: an ethnopragmatic and morphophonological study of personal names in Akan and some African societies. Munich: LINCOM.

Obeng, Samuel Gyasi. 2000a. "Speaking the Unspeakable: Discursive Strategies to Express Language Attitudes in Legon (Ghana) Graffiti." Research on Language and Social Interaction. 33(3): 291-319.

Obeng, Samuel Gyasi. 2000b. "Doing Politics on Walls and Doors: A Linguistic Analysis of Graffiti in Legon (Ghana)." Multilingua 19(4) 337-365.

Obeng, Samuel Gyasi. 1999. "Grammatical Pragmatics: Power in Akan Judicial Discourse.” Pragmatics 9:2.199-229.

Obeng, Samuel Gyasi. 1999. “Apologies in Akan Discourse.” Journal of Pragmatics 31(5): 709-734.

Obeng, Samuel Gyasi. 1997a. "Language and Politics: Verbal Indirection in Political Discourse." Discourse and Society 8 (1): 49-83.

Obeng, Samuel Gyasi. 1997b. "Communication strategies: Persuasion and politeness in Akan judicial discourse.” Text 17(1): 25-51. 
Gyasi Obeng: Language and Liberty in Ghanaian Political Communication: A Critical Discourse Perspective

Obeng, Samuel Gyasi. 1997c. "From morphophonology to sociolinguistics: The case of Akan hypocoristic day-names." Multilingua 16 (1): 39-56.

van Dijk, Teun. 2004. Communicating Ideologies. Multidisciplinary Perspectives on Language, Discourse and Social Practice. Frankfurt/Main: Peter Lang.

Watson Commission of Inquiry. 1948. Accra Riots. Accra. 